(c) American Dairy Science Association, 2006.

\title{
Characterization of a New Virulent Phage (MLC-A) of Lactobacillus paracasei
}

\author{
M. L. Capra, ${ }^{\star 1}$ A. del L. Quiberoni, ${ }^{*}$ H.-W. Ackermann,† S. Moineau, $\ddagger$ and J. A. Reinheimer* \\ *Instituto de Lactología Industrial (INLAIN), Facultad de Ingeniería Química (Universidad Nacional del Litoral), Santiago del Estero 2829, \\ 3000 Santa Fe, Argentina \\ †Département de Biologie Medícale, Faculté de Médicine, and \\ ¥Département de Biochimie et de Microbiologie, Faculté des Sciences et de Génie, Groupe de Recherche en Écologie Buccale (GREB), \\ Faculté de Médecine Dentaire, Félix d'Hérelle Reference Center for Bacterial Viruses, Université Laval, Quebec City, Quebec, \\ Canada, G1K 7P4
}

\section{ABSTRACT}

A new virulent bacteriophage (MLC-A) was recently isolated in Argentina from a probiotic dairy product containing a strain of Lactobacillus paracasei. Observation of the lysate with an electron microscope revealed bacteriophage particles with an icosahedral capsid of $57 \pm 2 \mathrm{~nm}$; with a collar and a noncontractile tail of 156 $\pm 3 \mathrm{~nm}$ terminating with a baseplate to which a tail fiber was attached. Therefore, phage MLC-A belongs to the Siphoviridae family. This phage was able to survive the pasteurization process and was resistant to alcohols and sodium hypochlorite $(400 \mathrm{mg} / \mathrm{kg})$. Only peracetic acid could inactivate high-titer suspensions of phages in a short time. The maximum rates of phage adsorption to its host cells were obtained at $30^{\circ} \mathrm{C}$ with a pH between 5 and 7, and in the presence of calcium or magnesium ions. The host range of phage MLC-A encompassed L. paracasei and Lactobacillus casei strains, but it was not able to infect Lactobacillus rhamnosus or Lactobacillus gasseri strains. One-step growth kinetics of its lytic development revealed latent and burst periods of 30 and $135 \mathrm{~min}$, respectively, with a burst size of about $69 \pm 4$ plaque-forming units per infected cell. Phage MLC-A had a distinctive restriction profile when compared with the 2 well-studied Lactobacillus phages, PL-1 and J-1. The genome size of the MLC-A phage was estimated to be approximately $37 \mathrm{~kb}$. This study presents the description of the first phage specific for $L$. paracase i isolated in Argentina. The isolation of phage MLC-A indicates that, beside lactic acid bacteria starters, probiotic cultures can also be sensitive to virulent phages in industrial processes.

Key words: Lactobacillus casei, bacteriophage, fermented milk

Received October 12, 2005.

Accepted February 20, 2006.

${ }^{1}$ Corresponding author: mcapra@fbcb.unl.edu.ar

\section{INTRODUCTION}

Globally, the dairy industry processes large volumes of milk each day under strict food safety guidelines, but it is still a nonsterile environment from a microbiological standpoint. Therefore, lactic acid bacteria starters are normally exposed to phages that are naturally present in milk (Moineau, 1999). Consequently, the fermentation process may be slowed or completely stopped, thereby reducing the quality of the final products (Forsman et al., 1993). Some species of Lactobacillus are used worldwide as industrial starters for the manufacture of fermented milk and cheese. Specific strains of Lactobacillus casei with probiotic characteristics are also used in functional foods and health products (Tynnkynen et al., 1999; Lee et al., 1999).

In comparison with phages of lactococci, the available knowledge about lactobacilli phages is limited and only a few of them have been studied in details (Séchaud et al., 1988; Moineau and Lévesque, 2005). Among them are some lytic Lactobacillus casei and Lactobacillus paracasei phages isolated from Yakult, a lactic acid beverage fermented with $L$. casei (phages PL-1 and J1; Watanabe et al., 1970; Yokokura, 1971) and cheeses (phage LC-Nu; Forsman et al., 1993), as well as the temperate phages FSW (Shimizu-Kadota and Tsuchida, 1984), A2 (Herrero et al., 1994), and AT3 (Lo et al., 2005). As Alvarez et al. (1999) stated, the expanding use of valuable Lactobacillus strains as starters and probiotics will eventually lead to an increase in the frequency of bacteriophage infections in dairy plants.

This work reports on the first phage (MLC-A) isolated in Argentina from a probiotic dairy product containing a commercial strain of $L$. paracasei. The aim of our study was to characterize this lytic bacteriophage in order to 1) implement thoroughly rational phage control strategies in industrial plants, and 2) compare it with the reference Lactobacillus phages PL-1 and J-1.

\section{MATERIALS AND METHODS}

Isolation of Phage MLC-A: Strains, Phages, and Culture Conditions

Phage MLC-A was isolated from an abnormal manufacture of an Argentinean probiotic dairy product fol- 
Table 1. Host range of phage MLC-A

\begin{tabular}{|c|c|c|c|}
\hline Organism & Strain & Source $^{1}$ & Sensitivity $^{2}$ \\
\hline \multirow[t]{16}{*}{ Lactobacillus paracasei } & ATCC 27092 & ATCC & + \\
\hline & $\mathrm{Yk}$ & Commercial strain & + \\
\hline & $\mathrm{Hn}$ & Commercial strain & + \\
\hline & Dn & Commercial strain & + \\
\hline & A & Commercial strain & + \\
\hline & A13 & Commercial strain & + \\
\hline & A14 & Commercial strain & + \\
\hline & Bio & Commercial strain & - \\
\hline & L26 & Commercial strain & - \\
\hline & SA & Commercial strain & - \\
\hline & PR & Commercial strain & - \\
\hline & CNRZ 1224 & CNRZ & - \\
\hline & CNRZ 1308 & CNRZ & - \\
\hline & CNRZ 318 & CNRZ & - \\
\hline & CNRZ 1976 & CNRZ & - \\
\hline & JP1 & INLAIN collection & - \\
\hline \multirow[t]{2}{*}{ Lactobacillus gasseri } & F37 & INLAIN collection & - \\
\hline & F37" & INLAIN collection & - \\
\hline \multirow[t]{6}{*}{ Lactobacillus casei } & ATCC 27139 & ATCC & + \\
\hline & ATCC 393 & ATCC & + \\
\hline & CNRZ 1874 & CNRZ & - \\
\hline & 8 & INLAIN collection & - \\
\hline & $\mathrm{M}$ & INLAIN collection & - \\
\hline & SA & Commercial strain & - \\
\hline \multirow[t]{12}{*}{ Lactobacillus rhamnosus } & GG & Commercial strain & - \\
\hline & A15 & Commercial strain & - \\
\hline & A16 & Commercial strain & - \\
\hline & F22 & INLAIN collection & - \\
\hline & F30 & INLAIN collection & - \\
\hline & F49 & INLAIN collection & - \\
\hline & F53 & INLAIN collection & - \\
\hline & F56 & INLAIN collection & - \\
\hline & F70 & INLAIN collection & - \\
\hline & F74 & INLAIN collection & - \\
\hline & F85 & INLAIN collection & - \\
\hline & F95 & INLAIN collection & - \\
\hline
\end{tabular}

${ }^{1}$ Source: ATCC, Manassas, VA; CNRZ collection, Jouy en Josas, Domaine de Vilvert, France; INLAIN collection, Santa Fe, Argentina.

${ }^{2}+=$ sensitive; $-=$ insensitive.

lowing the methodology described by Svensson and Christiansson (1991). This phage was deposited at the Félix d'Hérelle Reference Center for Bacterial Viruses (www.phage.ulaval.ca). The host commercial strain $L$. paracasei $\mathrm{A}$ was used for plaque counts and propagation of the phage. To test the host range of phage MLC-A, 16 strains of $L$. paracasei (5 collection strains, a strain isolated from infant feces, and 10 commercial strains), 6 strains of $L$. casei ( 5 collection strains and 1 commercial strain), 12 strains of Lactobacillus rhamnosus (3 commercial strains and 9 strains isolated from infant feces), and 2 strains of Lactobacillus gasseri (isolated from infant feces) were used. All Lactobacillus strains belonged to the Instituto de Lactología Industrial (INLAIN) collection (Santa Fe, Argentina). Phages PL-1 and J-1, obtained from the ATCC (American Type Culture Collection, Manassas, VA) and previously studied in our laboratory (Capra et al., 2004, 2006), were compared with the new phage MLC-A. Strains were main- tained as frozen stocks at $-80^{\circ} \mathrm{C}$ in de Man, Rogosa, and Sharpe (MRS) broth (Britania S.A., Buenos Aires, Argentina) supplemented with $15 \%$ (vol/vol) glycerol, and routinely cultured overnight at $37^{\circ} \mathrm{C}$ in MRS broth. Phage stocks were prepared as described by Neviani et al. (1992) in MRS broth, supplemented with $10 \mathrm{mM}$ $\mathrm{CaCl}_{2}$ (MRS-Ca), and stored at $4^{\circ} \mathrm{C}$ (MRS broth), and at $-80^{\circ} \mathrm{C}$ [MRS broth with $15 \%$ (vol/vol) glycerol]. Phage enumerations ( $\mathrm{pfu} / \mathrm{mL}$ ) were performed by the doublelayer plate titration method (Svensson and Christiansson 1991), using MRS agar with $10 \mathrm{mM} \mathrm{CaCl}$ and 100 $\mathrm{m} M$ glycine (Lillehaug, 1997). Plates were incubated at $34^{\circ} \mathrm{C}$ under microaerophilic conditions.

\section{Electron Microscopy}

Phage MLC-A was sedimented in a Beckman J2-21 ultracentrifuge (Beckman, Palo Alto, CA) using a JA18.1 swinging bucket rotor $(60 \mathrm{~min}$ at $25,000 \times \mathrm{g})$, and 


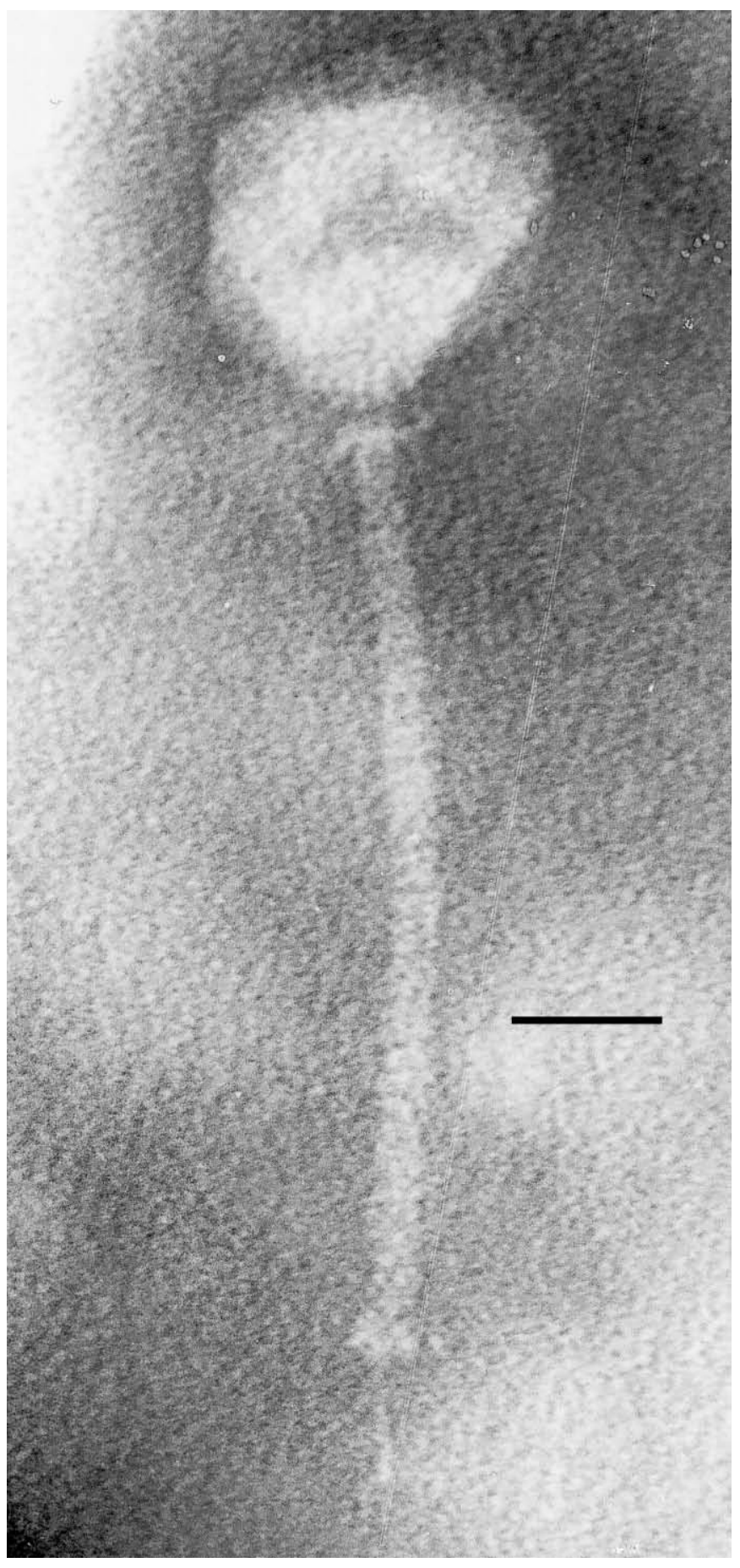

Figure 1. Electron micrograph of Lactobacillus paracasei phage MLC-A. Bar represents $25 \mathrm{~nm}$.

washed twice in $0.1 \mathrm{M}$ neutral ammonium acetate (60 $\min$ at $25,000 \mathrm{~g}$ ). Phages were deposited on carboncoated copper grids, colored with $2 \%$ (wt/vol) potassium phosphotungstate $(\mathrm{pH} 7.2)$, or $2 \%$ (wt/vol) uranyl acetate $(\mathrm{pH}$ 4.5), and examined with a Philips EM 300

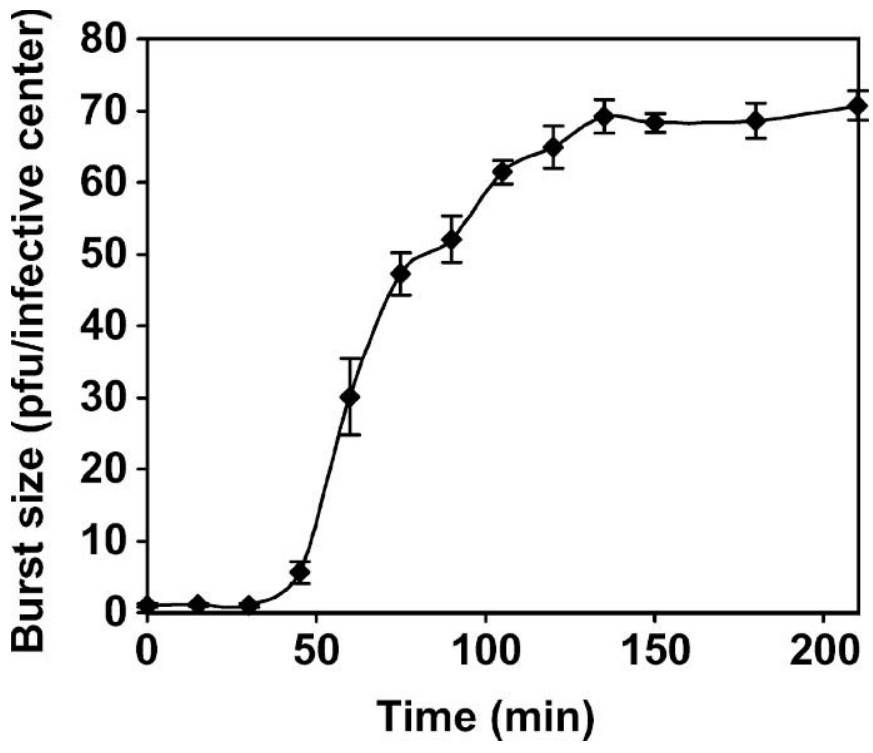

Figure 2. One-step growth curve of phage MLC-A on Lactobacillus paracasei $\mathrm{A}$. Values are the mean of 3 determinations.

electron microscope (Philips, Eindhoven, The Netherlands) operated at $60 \mathrm{kV}$. Magnification was monitored using T4 phage tails (113 $\mathrm{nm}$ in length).

\section{Host Range of Phage MLC-A}

Strain cross sensitivity was investigated using the spot and turbidity tests, as described by Svensson and Christiansson (1991). These assays were performed for the strains listed in Table 1.

\section{One-Step Growth Curve}

A midexponential phase culture of $L$. paracasei A (optical density at $560 \mathrm{~nm}=0.5$ ) was harvested and suspended in one-fifth of the initial volume of fresh MRS-Ca broth. Phages were added at a multiplicity of infection of 0.5, and allowed to adsorb for $30 \mathrm{~min}$ at $37^{\circ} \mathrm{C}$. Cells were harvested by centrifugation $(10,000 \times$ $\mathrm{g}, 5 \mathrm{~min}$ ), and resuspended in MRS-Ca broth. Decimal dilutions were made, incubated at $37^{\circ} \mathrm{C}$, and at intervals, aliquots from each dilution were collected for bacteriophage counts (Chow et al., 1988). Latent period, burst time, and burst size were calculated from the onestep growth curve.

\section{Influence of Divalent Cations on the Lytic Cycle}

The influence of divalent cations on cell lysis was investigated by incubation $\left(37^{\circ} \mathrm{C}\right)$ of infected L. paracasei A cultures in MRS broth with and without $\mathrm{CaCl}_{2}$ or $\mathrm{MgCl}_{2}$ (10 $\left.\mathrm{mM}\right)$. Plaque formation was investigated 


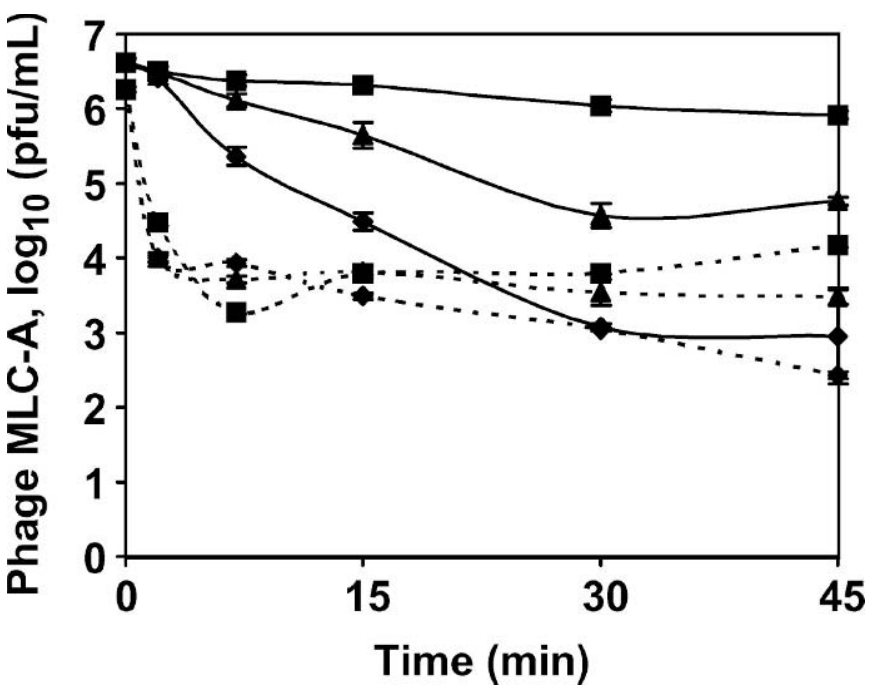

Figure 3. Inactivation kinetics of phage MLC-A at $63^{\circ} \mathrm{C} \mathrm{(-)} \mathrm{and}$ $72^{\circ} \mathrm{C}(--)$ in de Man, Rogosa, and Sharpe broth $(\diamond)$, Tris magnesium gelatin buffer $(\boldsymbol{\Delta})$, and reconstituted skim milk (ם). Values are the mean of the 3 determinations.

using the double-layer plate technique in MRS agar, with and without $\mathrm{CaCl}_{2}$ or $\mathrm{MgCl}_{2}$.

\section{Phage Stability}

Resistance to physical and chemical agents was determined according to the methods described previously (Capra et al., 2004). Thermal tolerance was assayed at 63,72 , and $90^{\circ} \mathrm{C}$, in 3 media: Tris magnesium gelatin buffer [10 $\mathrm{m} M$ Tris-Cl, $10 \mathrm{mM} \mathrm{MgSO}_{4}$, and $0.1 \%$ (wt/ vol) gelatin], MRS broth, and reconstituted skim milk. Resistance to biocides was determined using commercial sodium hypochlorite (200 to $600 \mathrm{mg} / \mathrm{kg}$ residualfree chlorine), ethanol (10, 50, 75 and $100 \% \mathrm{vol} / \mathrm{vol}$; Cicarelli, Buenos Aires, Argentina), isopropanol (10, 50 and $100 \% \mathrm{vol} / \mathrm{vol}$; Cicarelli), and peracetic acid $(0.15 \%$ vol/vol; Proxitane 1512, Química General, Santa Fe, Argentina). Results were expressed as the concentration $\left(\mathrm{pfu} / \mathrm{mL}\right.$ ) of active viral particles and its $\log _{10}$ plotted against time. Time (min) to achieve the 99\% inactivation $\left(\mathbf{T}_{\mathbf{9 9}}\right.$ ) of phages was calculated graphically from the inactivation curves as described by Quiberoni et al. (2003).

Phage stability was also examined in MRS broth at $\mathrm{pH}$ values ranging from 2 to 10 , after incubation for 30 min at $25^{\circ} \mathrm{C}$ and $37^{\circ} \mathrm{C}$ (Capra et al., 2006). The surviving phages were immediately counted and the results were expressed as a percentage of the initial viral counts.

Phage titers were also measured after storage at 4, -20 , and $-80^{\circ} \mathrm{C}$. Glycerol $(15 \% \mathrm{vol} / \mathrm{vol}$, final concentration) was added to MRS broth containing phage suspensions, and stored at $-20^{\circ} \mathrm{C}$ and $-80^{\circ} \mathrm{C}$. At predetermined intervals, aliquots were taken, and phages titers were measured by the double-layer plate method. Results were expressed as percentages of the initial viral counts.

\section{Phage Adsorption Studies}

The effect of calcium ions on phage adsorption was investigated by determination of adsorption kinetics as described by Séchaud et al. (1989), modified as follows: exponentially growing (optical density at $560 \mathrm{~nm}=0.5$ ) L. paracasei cultures in MRS broth were centrifuged and the cells resuspended $\left(3 \times 10^{8}\right.$ to $\left.5 \times 10^{8} \mathrm{cfu} / \mathrm{mL}\right)$ in MRS and MRS-Ca broths. Phages were added at a multiplicity of infection of 0.01 , and the mixtures were incubated at $37^{\circ} \mathrm{C}$. At predetermined intervals, aliquots were removed and centrifuged $(10,000 \times g, 5 \mathrm{~min})$ to sediment the phage-adsorbed cells. Then, the titers of unadsorbed free phages in the supernatant were determined as indicated above, and the results were expressed as percentages of the initial phage counts.

The influence of temperature on the adsorption rates of phage MLC-A on cells of $L$. paracasei A was evaluated as described above, but incubating the infected cultures at $0,10,20,30,37,45$, and $50^{\circ} \mathrm{C}$ for $30 \mathrm{~min}$ in MRS$\mathrm{Ca}$ broth. The counts of unadsorbed phages (doublelayer plate titration) were compared with the titer of a control without cells. The results were expressed as percentage of adsorption.

The adsorption of phage MLC-A on L. paracasei A was determined at $\mathrm{pH}$ values of $4,5,6,7,8,9$ and 10 , as previously described by Capra et al. (2006). This $\mathrm{pH}$ range was chosen taking into account the results of $\mathrm{pH}$ stability assays $\left(37^{\circ} \mathrm{C}\right)$. The results were expressed as percentage of adsorption and plotted against $\mathrm{pH}$ values.

Finally, the adsorption kinetics on thermally treated cells was also determined. Nonviable cells were obtained by placing a cell suspension in boiling water for 2 min (Quiberoni and Reinheimer, 1998). Viability loss was checked by plate counts on MRS agar.

\section{Restriction Analysis of Phage Double-Stranded DNA}

Phage DNA was obtained as reported elsewhere (Moineau et al., 1994). Purified DNA was digested with EcoRI and HindIII under the conditions recommended by the manufacturer (Roche Diagnostics, Laval, Quebec, Canada). After restriction, the DNA samples were heated for $10 \mathrm{~min}$ at $75^{\circ} \mathrm{C}$ to avoid possible cohesiveend ligation. Restricted DNA was electrophoresed on $0.8 \%$ (wt/vol) agarose gels in $1 \times$ Tris-acetate EDTA (0.04 $M$ Tris-acetate, $0.001 M$ EDTA), and visualized by UV photography after staining with ethidium bromide. The size of the MLC-A phage genome was estimated 

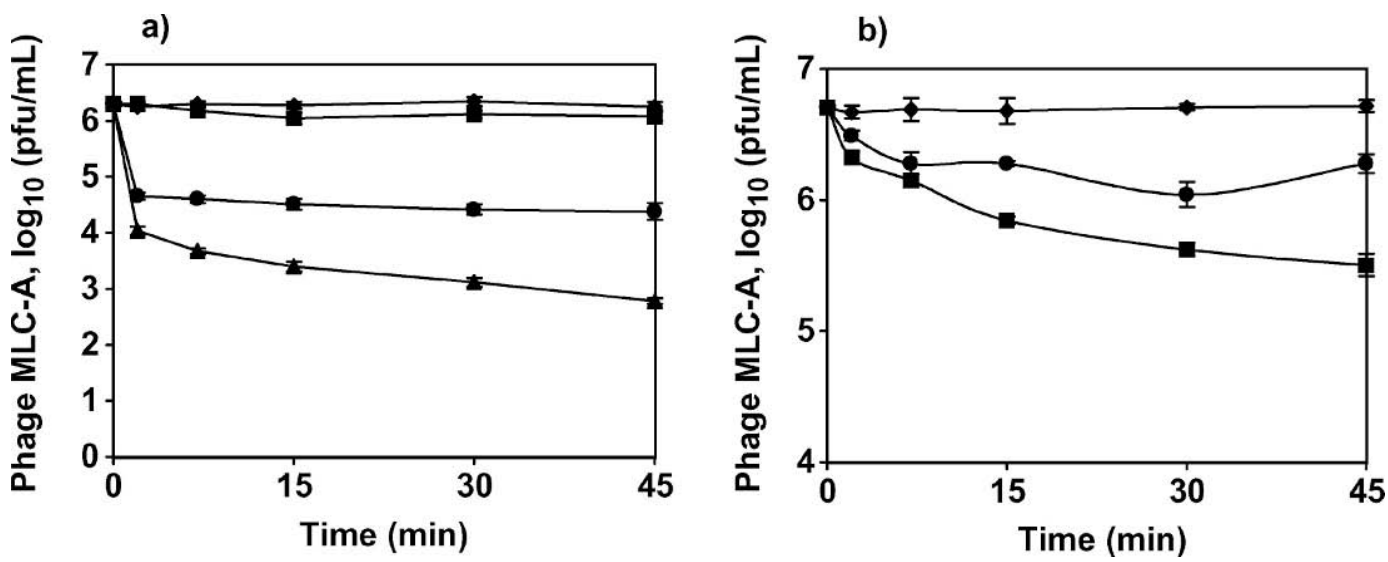

Figure 4. Inactivation kinetics of phage MLC-A in presence of a) $10 \%(\diamond), 50 \%(\boldsymbol{\square}), 75 \%(\boldsymbol{\Delta})$, and $100 \%(\bullet)$ ethanol, and b) $10 \%(\bullet)$, $50 \%$ ( $)$, and $100 \%$ ( isopropanol. Values are the mean of 3 determinations.

by adding the HindIII-digested DNA fragments. The DNA of phages PL-1 and J-1 were also obtained, purified, quantified, and digested with EcoRI and HindIII. The restriction patterns obtained were compared with that of the phage MLC-A.

\section{Statistical Analysis}

Experiments were replicated 3 times. All data were analyzed using the 1-way ANOVA procedure of SPSS (SPSS Inc., Chicago, IL). Differences among means were detected by Duncan's multiple range test (Lizasoain and Joaristi, 1995).

\section{RESULTS}

\section{Electron Microscopy}

The virulent phage MLC-A has an icosahedral capsid of $57 \pm 2 \mathrm{~nm}$ in diameter, with a collar of $12 \times 2 \mathrm{~nm}$, and a long noncontractile tail $156 \pm 3 \mathrm{~nm}$ long and 7 to $8 \mathrm{~nm}$ wide. The tail has a baseplate of $15 \times 3 \mathrm{~nm}$ to which a tail fiber of $20 \times 2 \mathrm{~nm}$ is attached (Figure 1 ). The phage was classified as a member of the Siphoviridae family and it is probably a member of the y5 species of Lactobacillus phages (Accolas and Spillmann, 1979; Ackermann and DuBow, 1987; Ackermann, 2001).

\section{Host Range}

As shown in Table 1, phage MLC-A was able to infect 7 of 16 strains of $L$. paracasei and 2 of 6 strains of $L$. casei. All the tested strains of $L$. rhamnosus and $L$. gasseri were insensitive to this phage.

\section{One-Step Growth Curve}

Multiplication parameters of the lytic cycle of phage MLC-A were determined from the one-step growth curve (Figure 2). The latent and burst periods were 30 and $135 \mathrm{~min}$, respectively, and the burst size was estimated at $69 \pm 4$ pfu per infected cell.

\section{Influence of Divalent Cations on the Lytic Cycle}

Divalent $\mathrm{Ca}^{2+}$ or $\mathrm{Mg}^{2+}$ was necessary for the lysis of the phage-infected cells in MRS broth and for the formation of visible phage MLC-A plaques in agar media. Magnesium ions were as efficient as calcium for cell lysis in broth. However, plaques with diffuse borders were obtained and the phage titer fell approximately $1 \log _{10}$ order when magnesium was added to the agar medium instead of calcium (data not shown). In the latter case, well-defined round $(0.8$ to $1.2 \mathrm{~mm}$ in diameter) lysis plaques were obtained.

\section{Phage Stability}

Phage MLC-A was able to survive thermal treatments commonly used in the dairy industry. Heating at 63 or $72^{\circ} \mathrm{C}$ was insufficient for complete inactivation of high-titer phage suspensions, even after $45 \mathrm{~min}$ (Figure 3). The reconstituted skim milk medium seemed to provide some protection to phages, because its $\mathrm{T}_{99}$ values were higher than those calculated for MRS broth and Tris magnesium gelatin buffer (Table 2). At $90^{\circ} \mathrm{C}$, the phage titers were reduced by $6 \log _{10}$ in all media tested after only 2 min.

When phage MLC-A suspensions were treated with biocides, phage titers were almost unaffected in the presence of isopropanol and the lowest concentrations (10 and $50 \%$, vol/vol) of ethanol. The most effective concentration of ethanol $(75 \%, \mathrm{vol} / \mathrm{vol})$ was able to reduce the phage titer by only $3.5 \log _{10}$ after 45 min (Figure 4 , Table 3 ). Sodium hypochlorite at $600 \mathrm{mg} / \mathrm{kg}$ was effective in producing undetectable counts $(<10 \mathrm{pfu} / \mathrm{mL})$ 
Table 2. Time needed to achieve 99\% inactivation of phage MLC-A particles at different temperatures and in various suspension media

\begin{tabular}{|c|c|c|c|c|c|c|c|c|c|}
\hline & & & & & Media & & & & \\
\hline & & RS bro & & & RSM & & & MG bu. & \\
\hline & $63^{\circ} \mathrm{C}$ & $72^{\circ} \mathrm{C}$ & $90^{\circ} \mathrm{C}$ & $63^{\circ} \mathrm{C}$ & $72^{\circ} \mathrm{C}$ & $90^{\circ} \mathrm{C}$ & $63^{\circ} \mathrm{C}$ & $72^{\circ} \mathrm{C}$ & $90^{\circ} \mathrm{C}$ \\
\hline Time (min) & 14.2 & 1.5 & $<2$ & $>45$ & 2.6 & $<2$ & 30 & 1.5 & $<2$ \\
\hline
\end{tabular}

${ }^{1}$ Media: MRS broth = de Man, Rogosa, and Sharpe broth; RSM = reconstituted skim milk; TMG buffer = Tris magnesium gelatin.

after 30 min (Figure 5), whereas peracetic acid $(0.15 \%$, $\mathrm{vol} / \mathrm{vol})$ was the most effective biocidal agent tested $\left(\mathrm{T}_{99}\right.$ value $<2 \mathrm{~min}$; Table 3 ).

Phage MLC-A maintained its infectivity when incubated at $25^{\circ} \mathrm{C}$ in a $\mathrm{pH}$ range between 4 and 10 (data not shown). At $37^{\circ} \mathrm{C}$, a slight decrease (approximately $30 \%$ ) in phage particle counts was observed at $\mathrm{pH} 6$

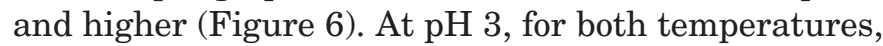
phages could not be detected $(<10 \mathrm{pfu} / \mathrm{mL}$; Figure 6$)$.

During storage, phage particles were kept intact for the first $3 \mathrm{mo}\left(\right.$ at $4^{\circ} \mathrm{C}$ ) or $5 \mathrm{mo}\left(\right.$ at $-20^{\circ} \mathrm{C}$ and $-80^{\circ} \mathrm{C}$ ). After 3 mo under refrigeration, a significant decrease in the number of infectious phages was noticed. By the end of the assay (15 mo), only $20 \%$ of phage particles were able to infect their host strain. When the phages were frozen, phage counts dropped by $20 \%$ between the fifth and the seventh month. After this initial reduction, the phage titers remained stable for the remaining period of the assay (Figure 7).

\section{Phage Adsorption Studies}

The presence of calcium in the medium had a significant $(P<0.01)$ influence on phage adsorption kinetics

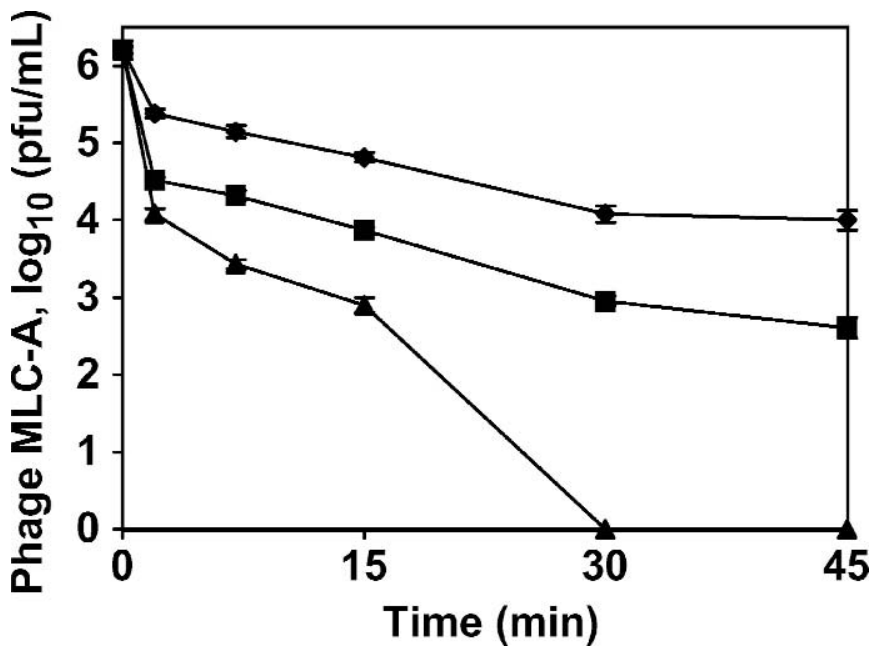

Figure 5. Inactivation kinetics of phage MLC-A in presence of $200(\bullet), 400(\square)$, and $600(\boldsymbol{\Delta}) \mathrm{mg} / \mathrm{kg}$ of residual-free chlorine. Values are the mean of 3 determinations.
(Figure 8a). Maximum adsorption rates of about $95 \%$ were achieved after $15 \mathrm{~min}$ incubation in the presence of calcium. On the other hand, when the medium was $\mathrm{Ca}^{2+}$ free, only $37 \%$ of the phages were adsorbed after $45 \mathrm{~min}$. Adsorption occurred within all the temperature ranges studied. Maximum (from 92 to $95 \%$ ) values of adsorption rates were achieved between 10 and $37^{\circ} \mathrm{C}$. Values fell to 59 and $78 \%$ at 0 and $50^{\circ} \mathrm{C}$, respectively (Figure $8 \mathrm{~b}$ ). Phage adsorption was strongly influenced by the $\mathrm{pH}$ of the medium (Figure 8c). High adsorption rates were obtained from $\mathrm{pH} 5$ to 7 but decreased at $\mathrm{pH} 4$ and 8, and were noticeably low at $\mathrm{pH} 9$ and 10 (10.3 and $1.7 \%$, respectively). The adsorption kinetics were significantly different when determined on viable and nonviable cells. The adsorption rates were higher on viable cells (approximately 30\%) as compared with those measured on nonviable cells (Figure 8d).

\section{Analysis of Phage DNA}

When EcoRI and HindIII restriction patterns of MLC-A phage were compared with those obtained for phages PL-1 and J-1, the former yielded a very distinctive restriction profile (Figure 9 ) confirming that MLCA was different from the 2 Lactobacillus reference phages. The genome size of phage MLC-A was approximately $37 \mathrm{~kb}$.

\section{DISCUSSION}

Currently, some industrial processes for the manufacture of fermented milks with probiotic strains include a prefermentation step in which the probiotic culture is grown to attain higher cell counts. This additional step may increase the frequency of phage attacks on commercially valuable probiotic bacteria. Phage MLC-A is the first $L$. paracasei bacteriophage isolated in Argentina from a probiotic dairy product. According to its morphology, this phage was classified as a member of the Siphoviridae family. Most of these phages, including MLC-A, have a base plate and a tail fiber (Watanabe et al., 1970; Yokokura, 1971; Shimizu-Kadota and Tsuchida, 1984; Forsman et al., 1993; Herrero et al., 1994; Lo et al., 2005), but to our knowledge, phage 
Table 3. Time needed to achieve 99\% inactivation of phage MLC-A particles in presence of various biocides

\begin{tabular}{|c|c|c|c|c|c|c|c|c|c|c|c|}
\hline & \multicolumn{11}{|c|}{ Biocide } \\
\hline & \multicolumn{4}{|c|}{$\begin{array}{l}\text { Ethanol } \\
(\% \text { vol/vol })\end{array}$} & \multicolumn{3}{|c|}{$\begin{array}{l}\text { Isopropanol } \\
\text { (\% vol/vol) }\end{array}$} & \multicolumn{3}{|c|}{$\begin{array}{l}\text { Sodium hypochlorite } \\
(\mathrm{mg} / \mathrm{kg})\end{array}$} & \multirow{2}{*}{$\begin{array}{l}\text { Peracetic acic } \\
\text { (\% vol/vol) }\end{array}$} \\
\hline & 10 & 50 & 75 & 100 & 10 & 50 & 100 & 200 & 400 & 600 & \\
\hline Time (min) & $>45$ & $>45$ & 1.8 & $>45$ & $>45$ & $>45$ & $>45$ & 27.8 & 9.2 & 1.9 & $<2$ \\
\hline
\end{tabular}

MLC-A is the only $L$. paracasei bacteriophage with a collar (also known as a neck passage structure).

The host range data provided an insight into the origins of new phages and the relationships among Lactobacillus phages as well as the development of information-based strategies to curb phage proliferation (Forde and Fitzgerald, 1999). Nine of the 36 Lactobacillus strains tested here were sensitive to phage MLCA. Phage MLC-A is highly specific for $L$. casei and $L$. paracase $i$ strains, and has the same host range as the reference phages PL-1 and J-1 (Capra et al., 2006). These findings suggest that phage MLC-A most likely uses the same host receptor as PL-1 and J-1, which involves L-rhamnose as a major component (Yokokura, 1971; Ishibashi et al., 1982). The MLC-A host range was broader than that observed with the Lactobacillus phage 393-A2, in which only 2 L. casei ssp. casei strains were sensitive among the 23 strains tested, belonging to 3 Lactobacillus species (L. plantarum, L. casei ssp. casei, L. casei ssp. rhamnosus, or L. brevis; Herrero et al., 1994).

Multiplication parameters (burst size and latent period) of phage MLC-A were found to be lower than those obtained for phages PL-1 (200 pfu/mL and $100 \mathrm{~min}$,

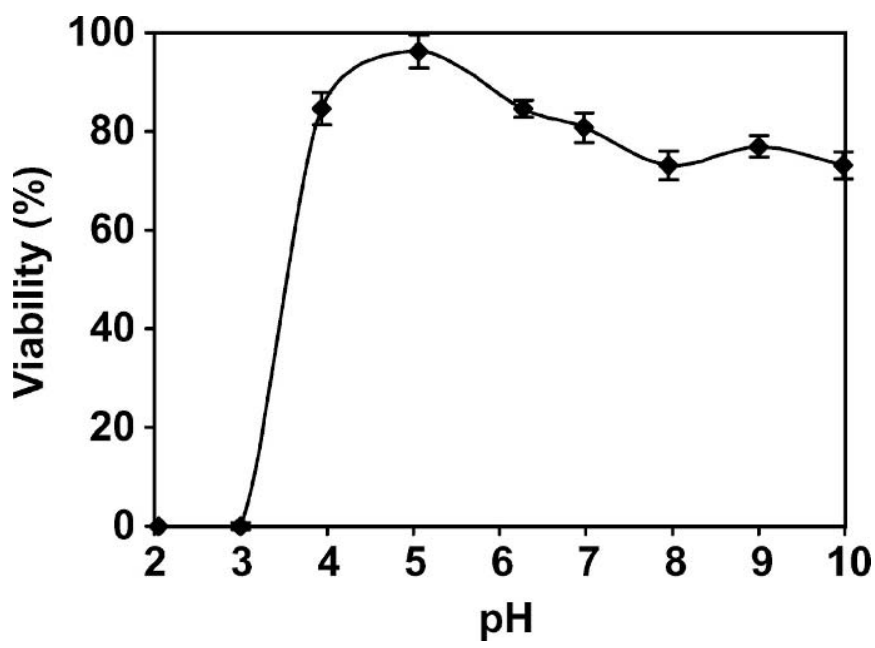

Figure 6. Effect of $\mathrm{pH}$ on phage MLC-A titer after incubation for 30 min in de Man, Rogosa, and Sharpe broth with calcium at $37^{\circ} \mathrm{C}$. Values are the mean of 3 determinations. respectively), 393-A2 (200 pfu/mL and $140 \mathrm{~min}$ ), and $\mathrm{J}-1$ (160 pfu/mL and $45 \mathrm{~min})$ on their sensitive ATCC strains (Watanabe et al., 1970; Herrero et al., 1994; Capra et al., 2006). However, these parameters were included in the range of values determined for phages PL-1 and J-1 on other host strains (Capra et al., 2006). Phage MLC-A burst size was identical to that obtained for FSW-TI (approximately $70 \mathrm{pfu} / \mathrm{mL}$ ), a temperate phage almost indistinguishable from FSV (Nes et al., 1988).

Although phages PL-1 and J-1 could achieve cell lysis in broth without $\mathrm{Ca}^{2+}$ or $\mathrm{Mg}^{2+}$ (Capra et al., 2006), phage MLC-A showed an absolute requirement for these ions to complete the cell lysis in broth and for the formation of visible plaques. However, calcium ions were more efficient than magnesium ions, leading to higher titers and clearer plaques. The same behavior was observed for phage J-1, whereas PL-1 produced diffuse lysis plaques ( 0.4 to $0.6 \mathrm{~mm}$ in diameter) only in the presence of $\mathrm{Ca}^{2+}$ ions (Capra et al., 2006).

The first step in the interaction between a lytic phage and its host happens when the phage particle adsorbs

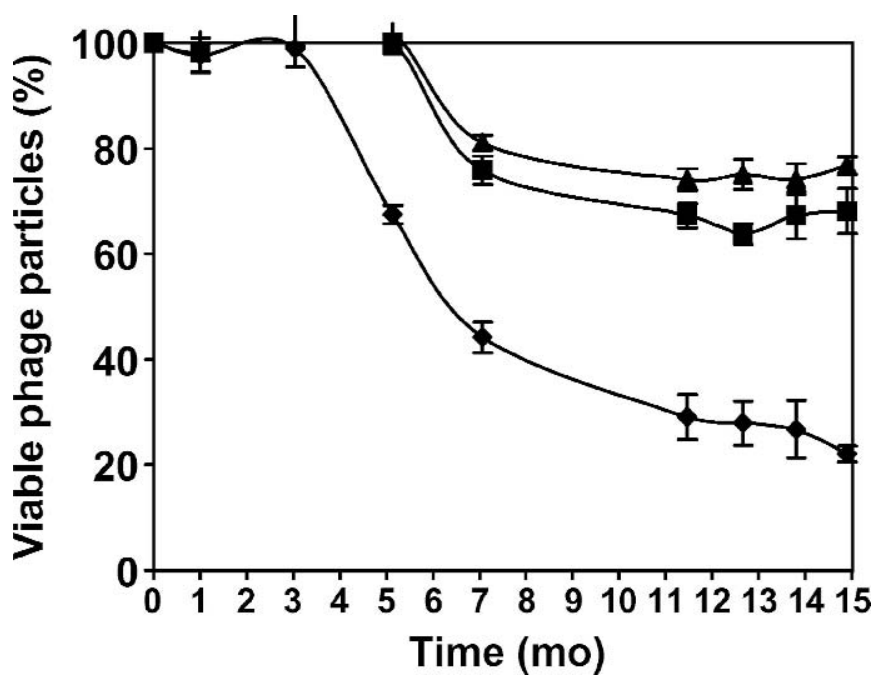

Figure 7. Changes in the titers of phage MLC-A during storage at $4^{\circ} \mathrm{C}$ ( $\bullet$ de Man, Rogosa, and Sharpe broth), $-20^{\circ} \mathrm{C}(\square)$, and $-80^{\circ} \mathrm{C}$ ( $\mathbf{\Delta}$; de Man, Rogosa, and Sharpe broth with glycerol 15\% vol/vol). Values are the mean of 3 determinations. 

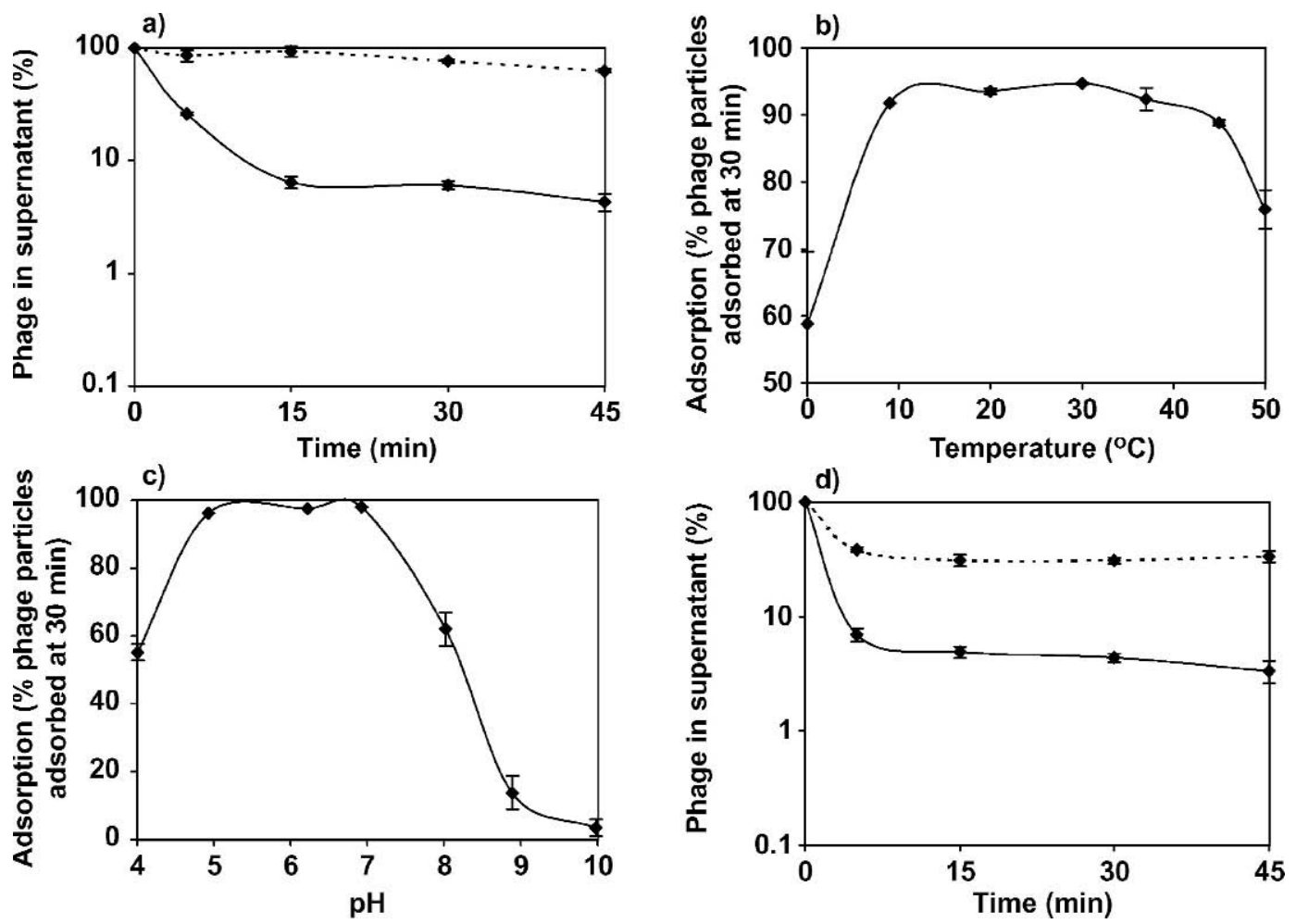

Figure 8. Effect of physical and chemical parameters on phage adsorption. a) Adsorption of phage MLC-A on cells of Lactobacillus paracasei A, in de Man, Rogosa, and Sharpe (MRS) broth with (-) and without (- -) $\mathrm{Ca}^{2+}(10 \mathrm{~m} M)$; b) Influence of temperature on the adsorption (after $30 \mathrm{~min}$ ) of phage MLC-A on Lactobacillus paracasei A, in MRS-Ca broth; c) Influence of $\mathrm{pH}$ on the adsorption of phage MLC-A on Lactobacillus paracasei A, in MRS-Ca broth; d) Influence of thermal treatment on cells, on the adsorption kinetics of phage MLCA on Lactobacillus paracasei A, in MRS-Ca broth on viable (-) and nonviable (- -) cells. For all the graphs, the values are the mean of 3 determinations.

on the cell surface. In the absence of $\mathrm{Ca}^{2+}$, lower adsorption rates were achieved for phage MLC-A even after 45 min of incubation, unlike all other $L$. casei and $L$. paracasei phages studied previously (Watanabe and Takesue, 1972; Capra et al., 2006). Adsorption rates for phage MLC-A on L. paracasei A were high and almost constant between 10 and $37^{\circ} \mathrm{C}$. However, adsorption curves obtained with the same strain but other phages (PL-1 and J-1) indicated stronger dependency on temperature (Capra et al., 2006). Regarding the influence of $\mathrm{pH}$ on adsorption, maximum rates were between $\mathrm{pH}$ 5 and $\mathrm{pH}$ 7. It is noteworthy that a decrease in phage counts was shown at $\mathrm{pH} 8$ and above; this could also affect the adsorption rates observed. In relation to the influence of the heat-treated sensitive cells on the adsorption of phage MLC-A, there was a clear decrease in the adsorption rates. Two reasons may explain these results. First, phage adsorption may be dependent on the physiological state of the cells, and second, the phage receptors may be thermosensitive.

The study of the different physicochemical parameters, which can affect the viability of phages, generated indispensable knowledge for devising effective control procedures to alleviate the devastating consequences of lytic bacteriophage attacks. It was evident that the usual pasteurization treatments were not adequate to completely inactivate phage MLC-A in milk. Some interesting differences were found by comparing the $\mathrm{T}_{99}$ values calculated for phage MLC-A with those for the reference phages PL-1 and J-1 (Capra et al., 2004). The former was much more resistant to thermal exposure at $63^{\circ} \mathrm{C}$, and especially at $72^{\circ} \mathrm{C}$.

It was previously observed that peracetic acid was the most effective biocide for lactic acid bacteria phages (Quiberoni et al., 1999, 2003; Binetti and Reinheimer, 2000; Suárez and Reinheimer, 2002; Capra et al., 2004). In agreement with these previous findings, phage MLCA was also readily inactivated by this chemical and in a short time. Thirty minutes in the presence of $600 \mathrm{mg} /$ $\mathrm{kg}$ of sodium hypochlorite was needed to inactivate this phage by $6 \log _{10}$. Interestingly, phages PL-1 and J-1 are more resistant to residual-free chlorine (Capra et al., 2004). Regarding alcohols, isopropanol and ethanol failed to inactivate phage MLC-A particles within 45 min, confirming the lack of effectiveness generally observed for these biocides against lactic acid bacteria 


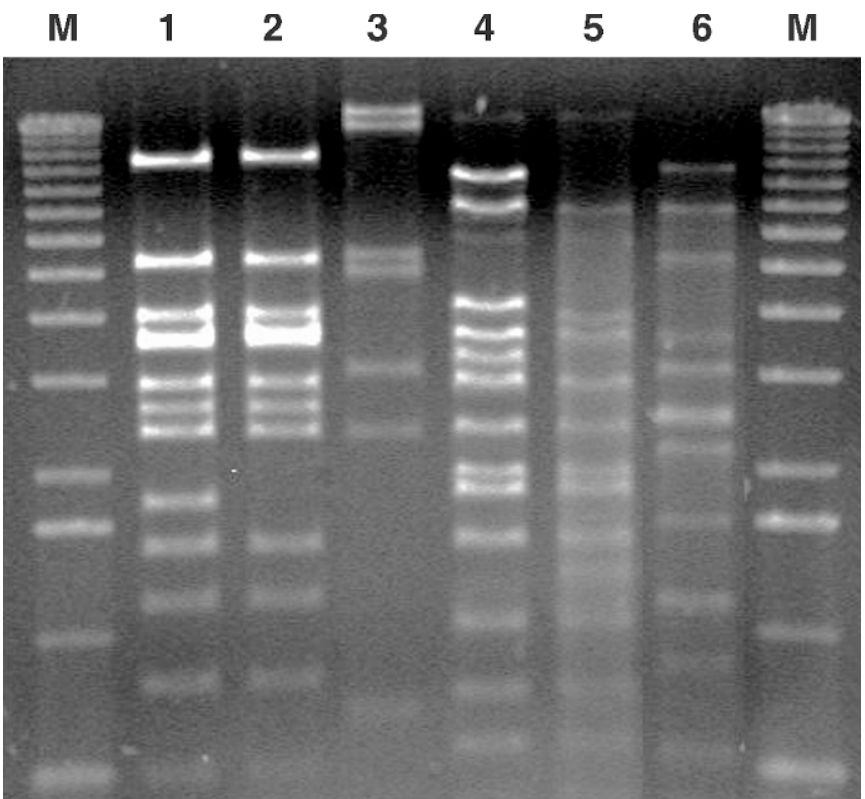

Figure 9. Agarose gel electrophoresis of the EcoRI- (lanes 1-3) and HindIII- (lanes 4-6) generated DNA fragments of phages. Lanes 1 and 4 = phage PL-1; lanes 2 and $5=$ phage J-1; lanes 3 and $6=$ phage MLC-A; lane M = $1 \mathrm{~kb}$ DNA ladder (Invitrogen, Carlsbad, CA) as molecular marker.

phages (Quiberoni et al., 1999, 2003; Binetti and Reinheimer, 2000; Suárez and Reinheimer, 2002; Capra et al., 2004).

The comparison of the DNA restriction patterns of phage MLC-A with PL-1 and J-1 clearly showed that phage MLC-A is different, and that phages PL-1 and $\mathrm{J}-1$ are closely related to each other. In fact, phages PL-1 and J-1 belong to a same serological group, and phage PL-1 is probably one of the host-range phage mutants derived from the parental phage J-1 (Watanabe et al., 1970). The genome size of phage MLC-A was estimated at $37 \mathrm{~kb}$, which is within the range found for other $L$. casei and $L$. paracasei phages known to date (Shimizu-Kadota and Tsuchida, 1984; Forsman et al., 1993; Herrero et al., 1994; Nakashima et al., 1994; Lo et al., 2005).

The several differences in the phenotypic and genotypic features of the phage MLC-A indicate that it is different from the 2 reference phages, PL-1 and J-1. Therefore, it represents a new phage specific for $L$. casei and $L$. paracase $i$ strains. Phage MLC-A is also the first phage of $L$. paracasei isolated in South America. In conclusion, this study provides knowledge on a new phage infecting a probiotic Lactobacillus strain that will lead to a better understanding of phage-host interactions, and to improved control measures to protect commercially valuable bacteria from phage attacks.

\section{ACKNOWLEDGMENTS}

This work was supported by the Consejo Nacional de investigaciones Científicas y Técnicas de Argentina (CONICET; Project PIP 02035/2000-2002), the Universidad Nacional del Litoral (Santa Fe, Argentina)Programación CAI+D 2002 (Proyecto no. 155), and the Agencia Nacional de Promoción Científica y Tecnológica de Argentina (ANPCyT; Project PICT 2001 no. 0908200). This work was also funded, in part, by a grant from the Natural Sciences and Engineering Research Council (NSERC) of Canada to S. Moineau.

\section{REFERENCES}

Accolas, J.-P., and H. Spillmann. 1979. Morphology of bacteriophages of Lactobacillus bulgaricus, L. lactis and L. helveticus. J. Appl. Bacteriol. 47:309-319.

Ackermann, H.-W. 2001. Frequency of morphological phage descriptions in the year 2000. Brief Review. Arch. Virol. 146:843-857.

Ackermann, H.-W., and M. S. DuBow. 1987. Viruses of prokaryotes. Vol. II. Natural group of bacteriophages. CRC Press, Boca Raton, FL.

Alvarez, M. A., A. Rodríguez, and J. E. Suárez. 1999. Stable expression of the Lactobacillus casei bacteriophage A2 repressor blocks phage propagation during milk fermentation. J. Appl. Microbiol. 86:812-816.

Binetti, A. G., and J. A. Reinheimer. 2000. Thermal and chemical inactivation of indigenous Streptococcus thermophilus bacteriophages isolated from Argentinian dairy plants. J. Food Prot. 63:509-515.

Capra, M. L., A. Quiberoni, and J. A. Reinheimer. 2006. Phages of Lactobacillus casei / paracasei: Response to environmental factors and interaction with collection and commercial strains. J. Appl. Microbiol. 100:334-342.

Capra, M. L., A. Quiberoni, and J. A. Reinheimer. 2004. Thermal and chemical resistance of Lactobacillus casei and Lactobacillus paracasei bacteriophages. Lett. Appl. Microbiol. 38:499-504.

Chow, J. J., C. A. Batt, and A. J. Sinskey. 1988. Characterization of Lactobacillus bulgaricus ch2. Appl. Environ. Microbiol. 54:1138-1142.

Forde, A., and G. F. Fitzgerald. 1999. Bacteriophage defense systems in lactic acid bacteria. Antonie Van Leeuwenhoek 76:89-113.

Forsman, P., J. Tanskanen, and T. Alatossava. 1993. Structural similarity and genetic homology between Lactobacillus casei bacteriophages isolated in Japan and in Finland. Biosci. Biotechnol. Biochem. 57:2043-2048.

Herrero, M., C. G. de los Reyes-Gavilán, J. L. Caso, and J. E. Suárez. 1994. Characterization of $\Phi 393-\mathrm{A} 2$, a bacteriophage that infects Lactobacillus casei. Microbiology 140:2585-2590.

Ishibashi, K., S. Takesue, K. Watanabe, and K. Oishi. 1982. Use of lectins to characterize the receptors sites for bacteriophage PL1 of Lactobacillus casei. J. Gen. Microbiol. 128:2251-2259.

Lee, Y. K., K. Nomoto, S. Salminen, and S. L. Gorbach. 1999. Introduction. Pages 1-22 in Handbook of Probiotics. John Wiley \& Sons, Inc, New York, NY.

Lillehaug, D. 1997. An improved plaque assay for poor plaque-producing temperate lactococcal bacteriophages. J. Appl. Microbiol. 83:85-90.

Lizasoain, L., and L. Joaristi. 1995. SPSS para windows, Versión 6.0 en castellano. Editorial Paraninfo, Buenos Aires, Argentina.

Lo, T. C., T. C. Shih, C. F. Lin, H. W. Chen, and T. H. Lin. 2005. Complete genomic sequence of the temperate bacteriophage AT3 isolated from Lactobacillus casei ATCC 393. Virology 339:42-55.

Moineau, S. 1999. Applications of phage resistance in lactic acid bacteria. Antonie Van Leeuwenhoek 76:377-382.

Moineau, S., and C. Lévesque. 2005. Control of bacteriophages in industrial fermentations. Pages 285-296 in Bacteriophages Biol- 
ogy and Applications. E. Kutter and A. Sulakvelidze, ed. CRC Press. Boca Raton, FL.

Moineau, S., S. Pandian, and T. R. Klaenhammer. 1994. Evolution of a lytic bacteriophage via DNA acquisition from the Lactococcus lactis chromosome. Appl. Environ. Microbiol. 60:1832-1841.

Nakashima, Y., H. Ikeda, Y. Kakita, F. Miake, and K. Watanabe. 1994. Restriction map of the genomic DNA of Lactobacillus casei bacteriophage PL-1 and nucleotide sequence of its cohesive singled-stranded ends. J. Gen. Virol. 75:2537-2541.

Nes, I. F., J. Brendehaug, and K. O. von Husby. 1988. Characterization of the bacteriophage B2 of Lactobacillus plantarum ATCC 8014. Biochimie 70:423-427.

Neviani, E. N., D. Carminati, and G. Giraffa. 1992. Selection of some bacteriophage- and lysozyme-resistant variants of Lactobacillus helveticus CNRZ 892. J. Dairy Sci. 75:905-913.

Quiberoni, A., and J. A. Reinheimer. 1998. Physicochemical characterization of phage adsorption to Lactobacillus helveticus ATCC 15807 cells. J. Appl. Bacteriol. 85:762-768.

Quiberoni, A., D. Guglielmotti, and J. A. Reinheimer. 2003. Inactivation of Lactobacillus delbrueckii bacteriophages by heat and biocides. Int. J. Food Microbiol. 84:51-62.

Quiberoni, A., V. B. Suárez, and J. A. Reinheimer. 1999. Inactivation of Lactobacillus helveticus bacteriophages by thermal and chemical treatments. J. Food Prot. 62:894-898.

Séchaud, L., M. L. Callegari, M. Rousseau, M. C. Muller, and J. P. Accolas. 1989. Relationship between temperate bacteriophage
0241 and virulent phage 832-B1 of Lactobacillus helveticus. Neth. Dairy J. 43:261-277.

Séchaud, L., P. J. Cluzel, M. Rousseau, A. Baumgartner, and J. P. Accolas. 1988. Bacteriophages of lactobacilli. Biochimie 70:401410.

Shimizu-Kadota, M., and N. Tsuchida. 1984. Physical mapping of the virion and the prophage DNAs of a temperate Lactobacillus phage FSW. J. Gen. Microbiol. 130:423-430.

Suárez, V. B., and J. A. Reinheimer. 2002. Effectiveness of therma treatments and biocides in the inactivation of Argentinian Lactococcus lactis phages. J. Food Prot. 65:1756-1759.

Svensson, V., and A. Christiansson. 1991. Methods for phage monitoring. FIL-IDF Bulletin 263:29-39.

Tynnkynen, S., R. Satokary, M. Saarela, T. Mattila-Sandholm, and M. Saxelin. 1999. Comparison of ribotyping, randomly amplified polymorphic DNA analysis, and pulsed-field gel electrophoresis in typing of Lactobacillus rhamnosus and L. casei strains. Appl. Environ. Microbiol. 65:3908-3914.

Watanabe, K., and S. Takesue. 1972. The requirement for calcium in infection with Lactobacillus phage. J. Gen. Virol. 17:19-30.

Watanabe, K., S. Takesue, K. Jin-Nai, and T. Yoshikawa. 1970. Bacteriophage active against the lactic acid beverage-producing bacterium Lactobacillus casei. Appl. Microbiol. 20:409-415.

Yokokura, T. 1971. Phage receptor material in Lactobacillus casei cell wall. I. Effect of L-rhamnose on phage adsorption to the cell wall. Jpn. J. Microbiol. 15:457-463. 